\section{Fransızca Yabancı Dil Öğrencilerinin Dil Öğrenmeye Yönelik İnançlarının Çeşitli Değişkenler Bağlamında İncelenmesi}

\author{
Zühre Yılmaz Güngör ${ }^{1}$
}

Türk Eğitim Bilimleri Dergisi

Makale Türü: Araştırma

Makale Geliş Tarihi: 19.02.20

Makale Kabul Tarihi: 21.08.20

Makale Yayın Tarihi: 28.12.20

ORCID: 0000-0002-1529-8749

\title{
Öz
}

Bu araştırmada, Fransızcayı yabancı dil olarak öğrenen 1., 2., 3. ve 4. sınıf öğrencilerinin dil öğrenmeye yönelik inançlarının çeşitli değişkenler açısından incelenmesi hedeflenmiştir. Araştırmanın verileri Horwitz (1988)'in İngilizceyi yabancı dil olarak öğrenen öğrencilerin dil öğrenmeye yönelik inançlarını tespit etmek için geliştirmiş olduğu "Dil Öğrenme ile İlgili İnançlar Envanteri" (BALLI- Beliefs About Language Learning Inventory) kullanılarak toplanmıştır. Araştırmanın verilerini analiz etmek için veri analiz programı (SPSS) ve çapraz tablolama yöntemi kullanılmıştır. "Katılımcıların Dil Öğrenmeye Yönelik İnanç Dağılımlarına İlişkin Bulgularına" bakıldığında, katılımcıların büyük çoğunluğu yabancı dil öğrenmede kızları ve erkekleri eşit düzeyde görmektedirler. Adayların bazı dillerin diğerlerine göre daha kolay öğrenildiği ve gelecekte Fransızca konuşmayı çok iyi öğrenebilecekleri konusunda hemfikir oldukları görülmektedir. Aynı zamanda, dili konuşabilmek için o dilin kültürüne de hâkim olmaları gerektiğini düşündükleri tespit edilmiştir. Böylelikle öğrencilerin, dil ve kültürün iç içe ve kelime dağarcığının da dili öğrenmede önemli olduğu konusunda duyarlı oldukları gözlenmiştir. Adayların, verdikleri yanıtlardan, sınıf düzeyi arttıkça, yabancı dilin hata yapılarak da konuşulabileceği, hata yapma korkusuyla çekingen kalınmaması gerektiği konusunda daha olumlu düşündükleri görülmektedir. Ayrıca, söz konusu ölçme aracına verilen yanıtlardan, katılımcıların güdülenme düzeylerinin yüksek olduğu söylenebilir.

Anahtar Sözcükler: Yabancı dil öğrenimi, Fransızca, İnançlar, Yabancı dil öğrencileri

\begin{abstract}
In this study, it is aimed to analyze the beliefs of first, second, third, and fourth grade students, studying French as a foreign language, about learning a language based on various variables. The quantitative data of the research were collected using the BALLI - Beliefs About Language Learning Inventory, which was developed by Horwitz (1988) in order to identify the beliefs of students studying English, about learning a language. The qualitative data analysis program (SPSS) and cross-tabulation method were used to analyze the qualitative data of the research. Examining the "Findings from the Belief Distribution of Participators in Language Learning", the majority of the participators recognize women and men equal in terms of learning a foreign language. It can be seen that the candidates think that certain languages are easier to learn, and that they will be able to learn French, having an excellent command of the same. It can also be seen that they lean towards the idea to have good knowledge of the culture of the language which they're learning. Therefore, what we conferred was that the students were aware of the significance of the vocabulary skills and that the language and the culture commune with each other. From the answers given by the candidates, it was also conferred that they were of the opinion that one can speak a language even if he/she makes a mistake and that making a mistake should not be recognized as a reason for lack of motivation. Moreover, it can also be said that the motivation levels of the participants are high.
\end{abstract}

Keywords: Foreign language learning, French, Beliefs, Foreign language students

${ }^{1}$ Zühre Yılmaz Güngör, Dr. Öğretim Üyesi, Anadolu Üniversitesi, zuhreyilmaz@gmail.com 


\section{Giriş}

Öğrenci merkezli eğitim anlayışının benimsenmesiyle, yapılan araştırmalarda öğrencilerin öğrenme sürecini etkileyen çeşitli etmenler üzerinde yoğunlaşmaya başlanmıştır. Buna bağlı olarak, öğrencilerin güdülenme, kaygı ve inanç gibi duygusal durumları araştırmaların odağı hâline gelmiştir.

Dolayısıyla, eğitim ve öğretim sürecinin her alanında olduğu gibi yabancı dil öğretiminde de öğrencilere daha iyi bir eğitim sağlamak için onları etkileyen psikolojik faktörlerin araştırılması gerekliliği ortaya çıkmıştır. Bu duygusal faktörlerin önemli bir kısmını da öğrencilerin dil öğrenimine yönelik inançları oluşturmaktadır. İnançlar, bireyin yaşadığı dünya ile ilgili anlayışları ya da önerileri olarak tanımlanmaktadır (Li 2011; Richardson 1996, aktaran Jee, 2013, s.399). Bernat ve Lloyd (2007, s.79) dil edinimi bağlamındaki inançlardan ise, "öğrencilerin kendileri, öğrenmeyi etkileyen faktörler, öğrenmenin ve öğretimin doğası hakkında sahip oldukları genel varsayımlar" olarak bahsetmektedir. Arnold'a (2006, s.419) göre, "bireyin tecrübeleri, ihtiyaçları ve değerleri üzerine inşa edilmiş olan inançlar davranışlarımızı şekillendirmektedir."

İnançların, yabancı dil öğrenimindeki rolü büyük önem teşkil etmektedir. Başarılı öğrenciler dil öğrenme sürecinde öğrenmeyi kolaylaştıracak birtakım inançlar geliştirmekle kalmaz, aynı zamanda kendi bireysel becerilerini ve etkili öğrenme stratejilerini de geliştirirler. Ancak, bazı öğrenciler yanlış veya olumsuz öğrenme inançlarına sahip olduklarından öğrenmeye karşı olumsuz bir tutum sergileyebilmektedirler. Örneğin, "yeni bir dil öğrenmenin çoğunlukla kelime ezberlemek olduğunu düşünen bir öğrenci, zamanının çoğunu kelime öğrenmeye harcayacaktır. Ya da daha genç öğrencilerin dil öğrenmede üstün olduklarını düşünen yetişkinler oldukça olumsuz bir beklentiyle dil öğrenmeye başlayabilirler" (Horwitz, 1988, s.283). Aynı şekilde, "yabancı bir dilin kazanılması için özel bir dil yeterliliğinin gerekli olduğuna inanan, ancak böyle bir yeterliliğe sahip olmadığını düşünen bir öğrenci, kendi başarısı hakkında oldukça olumsuz bir düşünceyle dil öğrenmeye başlayabilir" (Bernat ve Lloyd, 2007, s.80). Benzer dil yeterliliğine sahip öğrenciler arasında bile birtakım farklılıkların gözlenmesi, öğrencilerin sınıf içinde verilen görevlere farklı biçimde yaklaşmaları, bilim insanlarını bu alanda araştırma yapmaya itmiştir.

Bugüne kadar yabancı dil edinimi ile ilgili yapılan çalışmalarda, bireyin öğrenmeye yönelik sahip olduğu inançların oldukça dirençli olduğu ortaya konmuştur. Arnold'a (2006, s.419) göre inançlar öznelliğin bir sonucudur ve değiştirilmeleri zordur. Dolayısıyla, “disiplinler arası araştırmalar, inançların kimlik, öz-yeterlilik, kişilik özellikleri ve diğer bireysel farklılıklar gibi faktörlerle iç içe olduğunu göstermektedir (Bernat ve Lloyd, 2007, s.80). Bir başka araştırmacı Gabillon (2002, aktaran Dağgöl ve Akçayoğlu, 2017, s.137) ise, dil öğrenme inançlarının aşağıdaki kategorilerle ilişkili olduğundan bahsetmektedir:

- İkinci dil öğrencilerinin üst-bilişsel bilgisi, 
- Zihinsel ve sosyal temsiller,

- Özgüven (öz-yeterlilik inancı ve öz-kimlik inancı),

- Kontrol inancı, öz-düzenleyici inançlar,

- Öz-nitelikler.

Dolayısıyla, öğrencilerin yabancı dil öğrenme sürecinde öğrenmede farklılıklara yol açan etkenlerin incelenmesinin büyük önem taşıdığı kabul edilmektedir (Kaçar ve Zengin, 2009, s.56). “Bireysel öğrenme inançlarının rolü ve bu inançların dil öğrenenlerin öğrenme deneyimlerini nasıl etkilediği yirmi yıldan uzun bir süredir araştırmacıların ilgilendiği bir konudur" (Arığul, Ünal, Dalım ve Onursal, 2009, s.1500). Öğrencilerin sınıf ortamına beraberlerinde getirdikleri inançların öğrenme sürecini, başarıyı ve başarısızlığı önemli ölçüde etkilediği yapılan araştırmalar sonucunda ortaya konmuştur (Huang ve Tsai, 2003; Mori, 1997; Peacock, 2001). Bu bağlamda, “dil öğrenme inançlarına ilişkin çalışmalar, başarılı ve az başarılı öğrenciler arasındaki bireysel farklılıklarla ilgili araştırmalarla başlamıştır" (Altan, 2006, p.45). Horwitz'in (1988) yaptığı öncü çalışmanın ardından inançların sistematik olarak incelenmesine başlanmıştır. Horwitz, Dil Öğrenimine Yönelik İnançlar Envanteri (Beliefs About Language Learning Inventory- BALLI) olarak adlandırılan bir ölçek geliştirmiş ve Amerikalı üniversite öğrencilerinin yabancı dil öğrenimine yönelik inançlarını araştırmıştır. Yapılan bu çalışmanın sonucunda, öğrencilerin sahip oldukları önyargılı düşüncelerin onların dil öğrenme deneyimlerini olumsuz etkileyebileceği tespit edilmiştir. Hu (2010, aktaran Jee, 2013, s.402) 186 İngilizce yabancı dil öğrencisiyle yaptığı çalışmada, yüksek yeterlilik düzeyine sahip öğrencilerin düşük yeterlilik düzeyindekilere göre kendi öğrenme kabiliyetleri konusunda olumlu inançlara sahip olduklarını ve güdülenme düzeylerinin de yüksek olduğunu ortaya koymuştur. Kunt (2008, s.64) da öğrencilerin inançları üzerine yaptığı çalışmalar sonucunda, öğrencilerin dil öğrenmeye ilişkin inançlarının, yetenekleri ve dil öğrenme beklentileri üzerinde kritik etkilerinin olabileceğinden bahsetmektedir. Benzer şekilde, Bagherzadeh (2012, s.786) öğrencilerin inançlarının tutumlarını, istekliliklerini ve deneyimlerini etkilediğini, dolayısıyla öğrenmelerini engellediğini veya arttırdığını belirtmektedir. Banya ve Cheng'in (1997, s.20) kapsamlı çalışması güdülenme, tutum, güdülenme yoğunluğu, strateji kullanımı, kaygı ve başarı gibi faktörlerin öğrencilerin inançlarını etkilediğini tespit etmiştir. Araştırma sonucunda, tutumun öğrenmede en önemli faktör olduğu ve kaygının inançlarla olumsuz yönde ilişkili olduğu ortaya konmuştur. Ayrıca, olumlu bir tutuma sahip öğrencilerin sahip oldukları güçlü güdülenme ile daha az kaygılı oldukları tespit edilmiştir.

İnançların tespiti sadece öğrenmeyle ilişkili değildir, aynı zamanda öğretme üzerinde de etkilidir. Bernat ve Gvozdenko'nun $(2005$, p.8) belirttiği gibi öğrenci inançlarını ve bunların etkilerini, kullandıkları öğrenme stratejilerini ve öğrenmeden beklentilerini belirlemek okul müfredatının oluşturulmasında ve öğretmenlerin sınıf içi uygulamaları hakkında da fikir verebilmektedir. Bu 
nedenle, "öğrencilerini tanıyan bir öğretmen dersini daha etkili bir biçimde düzenleyebilmektedir" (Nikitina \& Furuoka, 2006, s.218).

Günümüze değin yapılan araştırmaların birçoğunda Horwitz'in geliştirmiş olduğu BALLI ölçeği kullanılmıştır ve genellikle İngilizceyi yabancı dil olarak ya da ikinci yabancı dil olarak öğrenen öğrencilerin dil öğrenmeye yönelik inançları araştırılmıştır. Ancak, Fransızcayı yabancı dil olarak öğrenen öğrencilerin dil öğrenimine ilişkin inançlarını tespit etmeye yönelik çalışmalar (Arnold, 2006; Jelakovic, 2014; Longpré, 2015) sınırlı sayıda olduğu için böyle bir araştırmaya gerek duyulmuştur. Ayrıca, "bugüne kadar yapılan çalışmalarda başlangıç seviyesindeki dil derslerine odaklanılmış, inançların ve tutumların yıllar arasındaki evrimi göz ardı edilmiştir”" (Kaçar ve Zengin, 2009, s.58). Bu nedenle, bu çalışmada sadece başlangıç düzeyindeki öğrencilerin değil, aynı zamanda eğitim düzeyine bağlı olarak inançlardaki muhtemel değişimin farklı sınıf düzeylerinde de incelenmesi ihtiyacı doğmuştur. Kısacası, inançlar, öğrencilerin zihinlerinde kendi öğrenmeleri hakkındaki fikirleri ve bunu nasıl şekillendirdikleri ile ilgilidir. Dolayısıyla, inançlar öğrenmeyi kolaylaştırdığı veya engellediğinden araştırılmaya değer bir kavram olarak karşımıza çıkmaktadır (Cephe ve Yalçın, 2015, aktaran Dağgöl ve Akçayoğlu, 2017, s.137).

Bu araştırmada, Fransızcayı yabancı dil olarak öğrenen 1., 2., 3. ve 4. sınıf öğrencilerinin dil öğrenmeye yönelik inançlarının çeşitli değişkenler açısından incelenmesi hedeflenmiştir. Bu çerçevede, aşağıdaki sorulara yanıt aranmıştır:

1. Yabancı dil Fransızca öğrencilerinin dil öğrenmeye yönelik inanç dağılımları nasıldır?

1.1. Yabancı dil yatkınlığı (Aptitude aux langues étrangères) bağlamında dağılımları nasıldır?

1.2. Dil öğrenme güçlügü (Difficulté d'apprentissage de langue) bağlamında dağılımları nasıldır?

1.3. Dil öğrenmenin doğası (Nature de l'apprentissage d'une langue) bağlamında dağılımları nasıldır?

1.4. Öğrenme ve iletişim stratejileri (Stratégies d'apprentissage et de communication) bağlamında dağılımları nasıldır?

1.5. Güdülenme ve beklentiler (Motivation et attentes) bağlamında dağılımları nasıldır?

2. Yabancı dil Fransızca öğrencilerinin dil öğrenmeye yönelik inanç dağılımları cinsiyet bağlamında nasıldır?

2.1. Yabancı dil yatkınlığı bağlamında cinsiyete göre dağılımları nasıldır?

2.2. Dil öğrenme güçlüğü bağlamında cinsiyete göre dağılımları nasıldır?

2.3. Dil öğrenmenin doğası bağlamında cinsiyete göre dağılımları nasıldır? 
2.4. Öğrenme ve iletişim stratejileri bağlamında cinsiyete göre dağılımları nasıldır?

2.5. Güdülenme ve beklentiler bağlamında cinsiyete göre dağılımları nasıldır?

3. Yabancı dil Fransızca öğrencilerinin dil öğrenmeye yönelik inanç dağılımları sınıf bağlamında nasıldır?

3.1. Yabancı dil yatkınlığı bağlamında sınıflara göre dağılımları nasıldır?

3.2. Dil öğrenme güçlüğü bağlamında sınıflara göre dağılımları nasıldır?

3.3. Dil öğrenmenin doğası bağlamında sınıflara göre dağılımları nasıldır?

3.4. Öğrenme ve iletişim stratejileri bağlamında sınıflara göre dağılımları nasıldır?

3.5. Güdülenme ve beklentiler bağlamında sınıflara göre dağılımları nasıldır?

\section{Yöntem}

Bu araştırmada Fransızca yabancı dil öğrencilerinin dil öğrenmeye yönelik inanç dağılımları cinsiyet ve sınıf bağlamında incelenmiştir. Araştırma betimsel bir çalışma olup tarama modelindedir. Tarama modelleri, "geçmişte ya da hâlen var olan bir durumu var olduğu şekliyle betimlemeyi amaçlayan araştırma yaklaşımlarıdır" (Karasar, 1995, s.77).

\section{Çalışma Grubu}

Araştırma, 2018 - 2019 eğitim - öğretim yılında Eskişehir'de bir devlet üniversitesinde Eğitim Fakültesi Yabancı Diller Eğitimi Bölümü Fransızca Öğretmenliği Programında öğrenim gören toplam $91(\mathrm{~K}=60, \mathrm{E}=31)$ öğrenci ile gerçekleştirilmiştir. Öğrenciler gönüllülük esasına dayalı olarak araştırmaya katılmışlardır. Öğrenciler, bahsedilen programın 1., 2., 3. ve 4. sınıflarında öğrenim görmektedirler ve Fransızcayı yabancı dil olarak öğrenmektedirler. Hazırlık sınıfında 1 yıllık bir eğitimin ardından lisans eğitimine devam etmelerinden dolayı yabancı dil düzeylerinin B1 ve B2 seviyelerinde olduğu kabul edilmektedir. Fransa'da doğup büyüyen ve ana dilleri Fransızca olan öğrenciler araştırma kapsamı dişında tutulmuştur.

Tablo 1. Öğretmen Adaylarına Ait Betimsel Bilgiler (Yüzdelik)

\begin{tabular}{ccccc}
\hline & & \multicolumn{2}{c}{ Cinsiyet } & \multirow{2}{*}{ Toplam } \\
\hline \multirow{2}{*}{1} & Sinıf içi & 60 & 40 & 100 \\
\multirow{4}{*}{2} & Cinsiyet içi & 30 & 39 & 33 \\
& Sinıf içi & 70 & 30 & 100 \\
\multirow{3}{*}{3} & Cinsiyet içi & 23 & 19 & 22 \\
& Sinnf içi & 68 & 32 & 100 \\
\multirow{3}{*}{4} & Cinsiyet içi & 28 & 26 & 28 \\
& Sinıf içi & 69 & 31 & 100 \\
\multirow{2}{*}{ Genel } & Cinsiyet içi & 18 & 16 & 18 \\
& Grup içi & 66 & 34 & 100 \\
& Cinsiyet içi & 100 & 100 & 100 \\
\hline \multirow{2}{*}{} & & & &
\end{tabular}




\section{Veri Toplama Araçları}

Araştırmanın verileri Horwitz'in (1988) İngilizceyi yabancı dil olarak öğrenen öğrencilerin dil öğrenmeye yönelik inançlarını tespit etmek için geliştirmiş olduğu “Dil Öğrenme ile İlgili İnançlar Envanteri (BALLI- Beliefs About Language Learning Inventory) kullanılarak toplanmıştır. Bu envanter, yabancı dil öğrenmede öğrenci inançları ile ilgili veri toplamada en çok kullanılan ve tercih edilen bir ölçme aracıdır. Öğrencilerin İngilizce yabancı dil bilgilerinin yeterli düzeyde olduğu varsayılarak ölçme aracı özgün dilinde kullanılmıştır. Sadece, envanterde geçen tüm "İngilizce" sözcükleri "Fransızca" olarak değiştirilmiştir. Envanter, öğrencilerin yabancı dile ilişkin inançlarını "Yabancı dil yatkınlığı" (Aptitude aux langues étrangères), “Dil öğrenmenin doğası” (Nature de l'apprentissage d'une langue), “Dil öğrenme güçlüğü" (Difficulté d'apprentissage de langue), "Öğrenme ve iletişim stratejileri" (Stratégies d'apprentissage et de communication), “Güdülenme ve beklentiler" (Motivation et attentes) başlıkları altında sınıflandırılmış 34 madde ile ölçmektedir. Maddelerin 2 tanesi (4. ve 14 . maddeler) çoktan seçmeli, diğerleri ise 5'li Likert türünde hazırlanmıştır. Envantere verilecek yanıtlar 1'den, 5'e kadar derecelendirilmiştir (1=Kesinlikle katılıyorum, 2=Katılıyorum, 3=Kararsızım, 4=Katılmıyorum, 5=Kesinlikle katılmıorum).

İlk boyutta yer alan maddeler 1, 2, 10, 15, 22, 29, 32, 33 ve 34'tür. İkinci boyutta ise 3, 4, 6, 14, 24 ve 28 numaralı maddeler bulunmaktadır. Envanterin üçüncü boyutunda 5, 8, 11, 16, 20, 25 ve 26 numaralı maddeler yer almaktadır. Envanterin dördüncü boyutunu 7, 9, 12, 13, 17, 18, 19 ve 21 numaralı maddeler oluşturmaktadır. Son alt boyutta ise 23, 27, 30 ve 31 numaralı maddeler bulunmaktadir.

\section{Verilerin Analizi}

Horwitz'in (1988) de belirttiği üzere envanterden toplam puan hesaplanması yerine katılımcıların maddelere göre dağılımlarının incelenmesi daha uygun bulunmuş ve araştırmada bu yol izlenmiştir. Araştırmanın nicel verilerini analiz etmek için nicel veri analiz programı (SPSS) ve çapraz tablolama yöntemi kullanılmıştır.

\section{Bulgular}

Araştırmaya katılan çalışma grubuna yönelik betimsel bulgular Tablo 1'de sunulmuştur. Tablo 1'de görüldüğü üzere araştırmaya 60'1 kadın olmak üzere toplam 91 öğretmen adayı katılmıştır. Tabloda görüldüğü üzere, araştırmaya katılan kadınların ve erkeklerin sınıf ve cinsiyet içinde yüzdelikleri birbirlerine benzer biçimde dağılmaktadır.

\section{Katılımcıların Dil Öğrenmeye Yönelik İnanç Dağılımlarına İlişkin Bulgular}

Çalışma grubunun dil öğrenmeye yönelik inançları ölçeğin alt boyutları olan Yabancı dil yatkınlığı, Dil öğrenme güçlüğ̈̈, Dil öğrenmenin doğası, Öğrenme ve iletişim stratejileri, Güdülenme ve 
beklentiler kapsamında incelenmiştir. Bu incelemede bulgular yüzdelik olarak sunulmuştur. Fransızca yabancı dil öğrencilerinin yabancı dil yatkınlığı bağlamındaki yönelimleri Tablo 2'de gösterilmektedir.

Tablo 2. Katılımcıların Yabancı Dil Yatkınlığına Yönelik Dağılımları

\begin{tabular}{lccccccccc}
\hline & m1 & $\mathbf{m} 2$ & $\mathbf{m 1 0}$ & $\mathbf{m 1 5}$ & $\mathbf{m 2 2}$ & $\mathbf{m 2 9}$ & $\mathbf{m 3 2}$ & $\mathbf{m 3 3}$ & $\mathbf{m 3 4}$ \\
\hline Kesinlikle Katılmiyorum & 0 & 6 & 1 & 1 & 36 & 39 & 11 & 23 & 3 \\
Katılmiyorum & 4 & 6 & 2 & 3 & 15 & 21 & 10 & 33 & 10 \\
Kararsizım & 4 & 3 & 9 & 24 & 25 & 14 & 24 & 31 & 14 \\
Katıliyorum & 25 & 43 & 42 & 46 & 10 & 17 & 31 & 7 & 28 \\
Kesinlikle Katıliyorum & 66 & 43 & 46 & 25 & 13 & 10 & 24 & 7 & 45 \\
\hline
\end{tabular}

Tablo 2'ye göre katılımcıların büyük bölümünün 22. maddede "Kesinlikle katılmıyorum,"; madde 1, madde 2, madde 10 ve madde 34 'te ise "Kesinlikle katıllyorum," yanıtında karar kıldıkları görülmektedir. Ayrıca, öğretmen adaylarının yabancı dil yatkınlıklarına yönelik inançlarının belirlenmeye çalışıldığı bu maddelerden en çok 33. maddede kararsız olduklarına yönelik görüş belirttikleri bulgusuna ulaşılmıştır. Bu durumda, katılımcıların büyük çoğunluğunun yabancı dil öğrenmede kadınların erkeklere göre daha başarılı olduğunu düşünmedikleri gözlenmiştir. Dolayısıyla, katılımcıların görüşlerine göre, yabancı dil öğrenmede cinsiyet faktörünün çok da önemli olmadığı söylenebilir. Ayrıca, yine katılımcıların büyük çoğunluğunun erken yaşta yabancı dil öğrenmenin daha kolay olduğu, bir yabancı dil bilmenin yeni bir yabancı dil öğrenmede kolaylık sağlayacağı ve Fransızcanın öğrenilmesi zor bir dil olduğu konusunda hemfikir oldukları görülmektedir. Aynı zamanda, yabancı bir dili öğrenmede doğuştan gelen bir takım becerilerin etkili olduğu görüşünde de hemfikirdirler. Buna göre, bazı kişilerin diğerlerine göre yabancı dili daha zor öğrenmelerinin nedeni olarak doğuştan gelen becerilerdeki eksikliğin etkili olduğu düşünülebilir.

Tablo 3'te katılımcıların dil öğrenme güçlüğüne yönelik yönelimlerine ilişkin bulgular yer almaktadır.

Tablo 3. Katılımcıların Dil Öğrenme Güçlüğüne Yönelik Dağılımları

\begin{tabular}{lcccccc}
\hline & m3 & m4 & m6 & m14 & m24 & m28 \\
\hline Kesinlikle Katılmiyorum & 0 & 1 & 0 & 0 & 18 & 7 \\
Katılmiyorum & 2 & 8 & 2 & 3 & 31 & 21 \\
Kararsizım & 17 & 39 & 17 & 17 & 28 & 25 \\
Katıliyorum & 40 & 42 & 40 & 56 & 13 & 19 \\
Kesinlikle Katıliyorum & 42 & 10 & 42 & 24 & 11 & 29 \\
\hline
\end{tabular}

Tablo 3'e göre öğretmen adaylarının büyük bölümünün 3. madde ve 6. maddede “Kesinlikle katılıyorum," yanıtında uzlaştıkları görülmektedir. Bu durumda adayların, bazı dillerin öğrenilmesinin diğerlerine göre daha kolay olduğu düşüncesinde oldukları ve ilerleyen yıllarda Fransızca konuşmayı çok iyi öğrenebileceklerini düşündükleri gözlenmektedir. Aynı zamanda, öğrencilerin 3., 4., 6., 14., 24 . ve 28 maddelerde de hemfikir oldukları ve "Katıllyorum," yanıtında yoğunlaştıkları görülmektedir. Buna göre, öğrenmiş oldukları dili ilerde çok iyi konuşabileceklerini, 
dil öğrenmenin uzun bir süreç olduğunu, Fransızcada okuma ve yazmanın, anlama ve konuşmaya göre daha kolay öğrenildiğini düşündükleri görülmektedir. Diğer yandan katılımcıların en çok katılmadıkları madde ise 24 olmuştur. Böylelikle, bir yabancı dili konuşmanın o dili anlamaya göre daha zor olduğunu düşünmeleri, yabancı dil öğretiminde konuşma becerisinin daha zor gelişen bir beceri olduğuna inandıklarını ortaya koymaktadır. Bulgulara göre, öğretmen adaylarının öğrenmeye çalıştıkları dilin zorluğuna yönelik soruda en kararsız durumda kaldıkları belirlenmiştir.

Tablo 4. Katılımcıların Dil Öğrenmenin Doğasına Yönelik Dağılımları

\begin{tabular}{lccccccc}
\hline & m5 & $\mathbf{m 8}$ & $\mathbf{m 1 1}$ & $\mathbf{m 1 6}$ & $\mathbf{m 2 0}$ & $\mathbf{m 2 5}$ & $\mathbf{m 2 6}$ \\
\hline Kesinlikle Katılmiyorum & 0 & 3 & 0 & 1 & 7 & 2 & 11 \\
Katılmiyorum & 0 & 12 & 0 & 8 & 19 & 3 & 10 \\
Kararsizım & 7 & 11 & 10 & 9 & 28 & 20 & 24 \\
Katıliyorum & 36 & 37 & 28 & 48 & 28 & 30 & 31 \\
Kesinlikle Katıliyorum & 57 & 36 & 63 & 34 & 20 & 45 & 24 \\
\hline
\end{tabular}

Çalışma grubunun dil öğrenmenin doğasına yönelik dağılımlarının verildiği Tablo 4'e göre katılımciların büyük bölümünün 5. madde, 11. madde ve 25. maddede "Kesinlikle katıllyorum," yanıtında birleştikleri belirlenmiştir. Buna göre, öğretmen adaylarının Fransızcanın dil yapısının Türkçenin dil yapısından farklı olduğunu, bir yabancı dili öğrenmenin en iyi yolunun o dilin konuşulduğu ülkede öğrenmek olduğunu, yabancı dil öğrenmenin diğer konuları öğrenmeye benzemediğini düşündükleri söylenebilir. Aynı zamanda, katılımcıların çoğunluğu bir dili konuşabilmek için o dilin kültürünü de öğrenmenin gerekli olduğunu düşünmektedirler. Böylelikle öğrencilerin, dil ve kültürün birbiriyle yakından ilişkili oluşu konusunda bilinçli oldukları söylenebilir. Yine, öğrencilerin çoğunluğunun 16. maddeye de "Katılıyorum," yanıtını verdikleri görülmektedir. Buna göre, yabancı dil öğrenmede kelime dağarcığının önemli olduğu konusunda hemfikir oldukları gözlenmektedir.

Diğer yandan, öğretmen adaylarının dil öğrenmenin doğasına yönelik bilgilerinin ölçüldüğü bu maddelerden en çok 20. maddede olumsuz yönde görüşte oldukları tespit edilmiştir. Katılımcıların en çok kararsız kaldıkları madde de yine bu madde olmuştur. Bu durumda, katılımcıların yabancı dil öğrenmenin sadece dilbilgisi kurallarını öğrenmek olmadığı konusunda bilinçli oldukları söylenebilir.

Tablo 5. Katılımcıların Öğrenme ve İletişim Stratejilerine Yönelik Dağılımları

\begin{tabular}{lcccccccc}
\hline & m7 & $\mathbf{m 9}$ & $\mathbf{m 1 2}$ & $\mathbf{m 1 3}$ & $\mathbf{m 1 7}$ & $\mathbf{m 1 8}$ & $\mathbf{m 1 9}$ & $\mathbf{m 2 1}$ \\
\hline Kesinlikle Katılmiyorum & 1 & 37 & 2 & 2 & 0 & 6 & 14 & 7 \\
Katılmiyorum & 14 & 34 & 6 & 4 & 1 & 4 & 20 & 17 \\
Kararsizım & 12 & 8 & 24 & 22 & 2 & 33 & 21 & 26 \\
Katıllyorum & 41 & 15 & 40 & 46 & 20 & 37 & 25 & 32 \\
Kesinlikle Katıliyorum & 32 & 6 & 29 & 25 & 77 & 20 & 20 & 19 \\
\hline
\end{tabular}


Çalışma grubunun öğrenme ve iletişim stratejilerine ilişkin dağılımlarının verildiği Tablo 5'te öğretmen adaylarının öğrenme ve iletişim stratejilerine yönelik inançlarında en çok tekrarın ve alıştırmanın öneminin vurgulandığı 17. maddenin ön planda olduğu belirlenmiştir. Aynı zamanda, yabancı dili mükemmel bir sesletim ve aksanla konuşmanın gerekliliğine inanmakta oldukları ve dili anadil düzeyinde konuşan kişilerle pratik yapma fırsatını değerlendirmek istedikleri görülmektedir. Diğer taraftan, 9. maddede ise katılımcıların büyük bölümünün görüşü duruma katılmadıkları yönündedir. Dolayısıyla, yabancı dil konuşurken hatalar yapılabileceği konusunda hemfikir oldukları görülmektedir. Ancak, öğretmen adaylarının en çok kararsız duruma düştükleri maddenin ise 18. madde olduğu görülmektedir. Bu durumda, katılımcıların birçoğunun yabancı dilde konuşurken kendilerini çekingen hissedebilecekleri ortaya çıkmaktadır.

Tablo 6. Katılımcıların Güdülenme ve Beklentilere Yönelik Dağılımları

\begin{tabular}{lcccc}
\hline & m23 & m27 & m30 & m31 \\
\hline Kesinlikle Katılmiyorum & 0 & 1 & 3 & 1 \\
Katılmıyorum & 0 & 2 & 9 & 4 \\
Kararsizım & 7 & 13 & 20 & 12 \\
Katıliyorum & 29 & 25 & 35 & 48 \\
Kesinlikle Katıliyorum & 65 & 58 & 33 & 34 \\
\hline
\end{tabular}

Envanterin bu alt alanı kapsamında, 23, 27, 30 ve 31. maddelere verilen yanıtlar incelenmiştir. Buna göre, katılımcıların güdülenme ve beklentiler doğrultusundaki yönelimlerinin verildiği Tablo $6^{\prime}$ da öğretmen adaylarının genel olarak maddelere olumlu yanıtlar verdikleri görülmektedir. Bu olumlu yanıtların sırasıyla 23. madde, 27. madde, 30. madde ve 31. madde olduğu belirlenmiştir. Dolayısıyla, öğretmen adayları bir yabancı dili konuşmanın önemli olduğunu (Türklerin yabancı bir dili konuşabilmeye önem verdiklerini), dili iyi konuşabilmenin o dili kullanmak için kendilerine çeşitli fırsatlar yaratacağını, iyi bir iş imkânı sağlayacağını, dilin konuşulduğu ülkenin insanlarını tanımada kolaylık sağlayacağını düşünmektedirler. Buna göre, katılımcıların yabancı dilde iletişim kurmaya önem verdikleri, güdülenmelerinin ve beklentilerinin oldukça yüksek olduğu söylenebilir.

\section{Katılımcıların Dil Öğrenmeye Yönelik İnançlarının Cinsiyet Bağlamındaki Dağılımlarına İlişkin Bulgular}

Çalışmanın ikinci araştırma sorusu kapsamında öğretmen adaylarının inançları yabancı dil yatkınlığı, dil öğrenme güçlüğü, dil öğrenmenin doğası, öğrenme ve iletişim stratejileri ve güdülenme ve beklentiler kapsamında incelenmiştir. Bu süreçte çapraz tablolama yöntemi işe koşulmuş ve bulgular yüzdelik olarak sunulmuştur. 
Tablo 7. Katılımcıların Cinsiyet Bağlamında Dil Öğrenme Yatkınlığı Dağılımları

\begin{tabular}{|c|c|c|c|c|c|c|c|c|c|c|c|c|c|c|c|c|c|c|}
\hline & \multicolumn{2}{|c|}{$\mathbf{m} 1$} & \multicolumn{2}{|c|}{$\mathrm{m} 2$} & \multicolumn{2}{|c|}{ m10 } & \multicolumn{2}{|c|}{ m15 } & \multicolumn{2}{|c|}{$\mathrm{m} 22$} & \multicolumn{2}{|c|}{ m29 } & \multicolumn{2}{|c|}{ m32 } & \multicolumn{2}{|c|}{ m33 } & \multicolumn{2}{|c|}{ m34 } \\
\hline & K & E & $\mathbf{K}$ & E & $\mathbf{K}$ & E & $\mathbf{K}$ & E & $\mathbf{K}$ & E & $\mathbf{K}$ & E & $\mathbf{K}$ & E & $\mathbf{K}$ & E & $\mathbf{K}$ & E \\
\hline 1 & 0 & 0 & 3 & 10 & 0 & 3 & 0 & 3 & 28 & 52 & 30 & 55 & 7 & 19 & 22 & 26 & 3 & 3 \\
\hline 2 & 5 & 3 & 3 & 10 & 3 & 0 & 3 & 3 & 15 & 16 & 20 & 23 & 13 & 3 & 33 & 32 & 15 & 0 \\
\hline 3 & 5 & 3 & 3 & 3 & 5 & 16 & 27 & 19 & 28 & 19 & 17 & 10 & 23 & 26 & 33 & 26 & 12 & 19 \\
\hline 4 & 20 & 36 & 48 & 32 & 53 & 19 & 47 & 45 & 10 & 10 & 22 & 7 & 30 & 32 & 7 & 7 & 33 & 16 \\
\hline 5 & 70 & 58 & 42 & 45 & 38 & 61 & 23 & 29 & 18 & 3 & 12 & 7 & 27 & 19 & 5 & 10 & 37 & 61 \\
\hline
\end{tabular}

1: Kesinlikle katılmıyorum, 2: Katılmıyorum, 3: Kararsızım, 4: Katılıyorum, 5: Kesinlikle katılıyorum

Tablo 7’ye göre çalışma grubunun cinsiyet bağlamındaki dil öğrenme yatkınlıkları dağılımlarında en büyük farklılıkların 10., 22., 29. ve 34. maddelerde olduğu belirlenmiştir. 10. ve 34 . maddelerde en büyük fark "Kesinlikle katılıyorum" yanıtlarında yaşanırken, diğer iki maddede ise tersi durum (Kesinlikle katılmıyorum) görülmüştür. Bu durumda, araştırmaya katılan erkek öğrenciler öncesinde yabancı bir dil bilen kişilerin ikinci dili bilmeyenlere göre daha kolay öğrenebileceklerini ve herkesin yabancı bir dil öğrenebileceğini düşünmektedirler. Buna göre 22. ve 29. maddelerde katılımcılar arasında cinsiyet bağlamında en büyük fark, "Kesinlikle katılmıyorum," yanıtında belirlenmiş̧tir. Sonuç olarak, kız öğrencilerin bir kısmının erkeklere göre yabancı dil öğrenmeye daha yatkın olduklarını düşündükleri görülmektedir. Erkek öğrencilerin büyük çoğunluğu ise verdikleri yanıtla bu maddeye kesinlikle katılmadığını belirtmiş ve cinsiyet faktörünün dil öğrenmeye yatkınlık konusunda etkili olmadığını düşündüklerini göstermişlerdir.

Tablo 8. Katılımcıların Cinsiyet Bağlamında Dil Öğrenme Güçlüğü Dağılımları

\begin{tabular}{|c|c|c|c|c|c|c|c|c|c|c|c|c|}
\hline & \multicolumn{2}{|c|}{$\mathrm{m} 3$} & \multicolumn{2}{|c|}{$\mathrm{m} 4$} & \multicolumn{2}{|c|}{$\mathrm{m} 6$} & \multicolumn{2}{|c|}{ m14 } & \multicolumn{2}{|c|}{$\mathrm{m} 24$} & \multicolumn{2}{|c|}{$\mathrm{m} 28$} \\
\hline & $\mathbf{K}$ & $\mathrm{E}$ & $\mathbf{K}$ & $\mathrm{E}$ & $\mathbf{K}$ & $\mathrm{E}$ & $\mathbf{K}$ & $\mathbf{E}$ & $\mathbf{K}$ & $\mathrm{E}$ & $\mathbf{K}$ & $\mathbf{E}$ \\
\hline 1 & 0 & 3 & 0 & 3 & 0 & 0 & 0 & 0 & 15 & 23 & 3 & 13 \\
\hline 2 & 3 & 3 & 8 & 7 & 2 & 3 & 3 & 3 & 35 & 23 & 23 & 16 \\
\hline 3 & 3 & 0 & 40 & 36 & 18 & 13 & 22 & 7 & 27 & 29 & 27 & 23 \\
\hline 4 & 38 & 19 & 40 & 45 & 43 & 32 & 53 & 61 & 12 & 16 & 22 & 13 \\
\hline 5 & 55 & 74 & 12 & 7 & 37 & 52 & 22 & 29 & 12 & 10 & 25 & 36 \\
\hline
\end{tabular}

1: Kesinlikle katılmıyorum, 2: Katılmıyorum, 3: Kararsızım, 4: Katılıyorum, 5: Kesinlikle katılıyorum

Çalışma grubunun dil öğrenme güçlüğü kapsamında cinsiyet bağlamında en büyük farklılıkların 3., 6. ve 28. maddelerde olduğu belirlenmiştir. Tablo 8' de görüldüğüü üzere her üç soruda da en büyük farkın "Kesinlikle katılıyorum," yanıtında yaşanması ilgi çekici bir bulgudur. Bu durumda, hem kız hem de erkek öğrencilerin büyük çoğunluğu bazı dillerin daha kolay öğrenildiğini, öğrenmekte oldukları dili (Fransızcayı) ileride iyi düzeyde konuşabileceklerini ve Fransızcayı okuyup yazmanın, anlamaya ve konuşmaya göre daha kolay olduğunu düşünmektedirler. 
Tablo 9. Katılımcıların Cinsiyet Bağlamında Dil Öğrenmenin Doğası Dağılımları

\begin{tabular}{|c|c|c|c|c|c|c|c|c|c|c|c|c|c|c|}
\hline & \multicolumn{2}{|c|}{ m5 } & \multicolumn{2}{|c|}{$\mathrm{m} 8$} & \multicolumn{2}{|c|}{ m11 } & \multicolumn{2}{|c|}{ m16 } & \multicolumn{2}{|c|}{$\mathrm{m} 20$} & \multicolumn{2}{|c|}{ m25 } & \multicolumn{2}{|c|}{$\mathrm{m} 26$} \\
\hline & K & E & $\mathbf{K}$ & E & $\mathbf{K}$ & E & $\mathbf{K}$ & E & $\mathbf{K}$ & E & $\mathbf{K}$ & E & $\mathbf{K}$ & E \\
\hline 1 & 0 & 0 & 3 & 3 & 1 & 0 & 0 & 3 & 2 & 16 & 2 & 3 & 12 & 13 \\
\hline 2 & 4 & 0 & 15 & 7 & 2 & 0 & 8 & 7 & 18 & 19 & 3 & 3 & 22 & 19 \\
\hline 3 & 10 & 0 & 10 & 13 & 10 & 10 & 10 & 7 & 32 & 19 & 20 & 19 & 32 & 23 \\
\hline 4 & 38 & 32 & 40 & 32 & 32 & 19 & 52 & 42 & 32 & 19 & 35 & 19 & 23 & 29 \\
\hline 5 & 52 & 68 & 32 & 45 & 58 & 71 & 30 & 42 & 17 & 26 & 40 & 55 & 12 & 16 \\
\hline
\end{tabular}

1: Kesinlikle katılmıyorum, 2: Katılmıyorum, 3: Kararsızım, 4: Katılıyorum, 5: Kesinlikle katılıyorum

Tablo 9'da sunulduğu üzere, dil öğrenmenin doğası alt boyutunun cinsiyet bağlamında neredeyse her maddede farklılık olduğu gözlenmektedir. "Kesinlikle katılıyorum," yanıtına erkek öğrencilerin her maddede kız öğrencilere göre yüksek yanıt verdikleri belirlenmiştir. Tüm tablo dikkate alındığında erkeklerin kızlara göre "Kesinlikle katılmıyorum,", "Katılmıyorum," ve “Kararsızım,” yanıtlarına daha az başvurdukları görülmüştür.

Tablo 10. Katılımcıların Cinsiyet Bağlamında Öğrenme İletişim Stratejileri Dağılımları

\begin{tabular}{|c|c|c|c|c|c|c|c|c|c|c|c|c|c|c|c|c|}
\hline & \multicolumn{2}{|c|}{$\mathrm{m} 7$} & \multicolumn{2}{|c|}{$\mathrm{m} 9$} & \multicolumn{2}{|c|}{ m12 } & \multicolumn{2}{|c|}{ m13 } & \multicolumn{2}{|c|}{ m17 } & \multicolumn{2}{|c|}{ m18 } & \multicolumn{2}{|c|}{ m19 } & \multicolumn{2}{|c|}{$\mathrm{m} 21$} \\
\hline & K & E & K & E & K & E & $\mathbf{K}$ & E & $\mathbf{K}$ & E & $\mathbf{K}$ & E & $\mathbf{K}$ & E & $\mathrm{K}$ & E \\
\hline 1 & 2 & 0 & 42 & 29 & 0 & 7 & 0 & 7 & 0 & 0 & 7 & 3 & 15 & 13 & 5 & 10 \\
\hline 2 & 13 & 16 & 27 & 48 & 5 & 7 & 7 & 0 & 2 & 0 & 3 & 7 & 18 & 23 & 15 & 19 \\
\hline 3 & 12 & 13 & 10 & 3 & 25 & 22 & 20 & 26 & 2 & 3 & 33 & 32 & 25 & 13 & 27 & 26 \\
\hline 4 & 40 & 42 & 17 & 13 & 47 & 26 & 52 & 36 & 23 & 13 & 37 & 39 & 22 & 32 & 35 & 26 \\
\hline 5 & 33 & 29 & 5 & 7 & 23 & 39 & 22 & 32 & 73 & 84 & 20 & 19 & 20 & 19 & 18 & 19 \\
\hline
\end{tabular}

1: Kesinlikle katılmıyorum, 2: Katılmıyorum, 3: Kararsızım, 4: Katılıyorum, 5: Kesinlikle katılıyorum

Öğrenme ve iletişim stratejileri alt boyutunun cinsiyet bağlamındaki en büyük farlılıkların 9., 12., 13. ve 17. maddelerde olduğu görülmektedir. Bu maddelerden 12., 13. ve 17. maddelerde erkek öğrencilerin "Kesinlikle katılıyorum," yanıtını kız öğrencilere göre daha fazla seçtikleri görülmüştür. Buna göre, kız öğrencilerin aksine, erkek öğrencilerin daha çok Fransızca konuşan kişilerle dili kullanmayı tercih ettiklerini, bilemedikleri bir sözcügün anlamını tahmin etmeye çalıştıklarını ve bol bol tekrar ve pratik çalışmalar yapmanın gerekli olduğunu düşündükleri tespit edilmiştir.

Öte yandan, 9. maddede kız öğrenciler erkeklere göre "Kesinlikle katılmıyorum," yanıtını tercih etmişlerdir. Bu durumda, kız öğrenciler hiç hata yapmadan Fransızca konuşulamayacağını, hatalara rağmen bu dili kullanmaya çalışmaları gerektiğini düşünmektedirler. 
Tablo 11. Katılımcıların Cinsiyet Bağlamında Güdülenme ve Beklentiler Dağılımları

\begin{tabular}{ccccccccc}
\hline & \multicolumn{2}{c}{ m23 } & \multicolumn{2}{c}{ m27 } & \multicolumn{2}{c}{ m30 } & \multicolumn{2}{c}{ m31 } \\
& K & E & K & E & K & E & K & E \\
\hline 1 & 0 & 0 & 0 & 3 & 0 & 10 & 0 & 3 \\
2 & 4 & 0 & 2 & 3 & 10 & 7 & 5 & 3 \\
3 & 8 & 3 & 17 & 7 & 20 & 19 & 13 & 10 \\
4 & 30 & 26 & 28 & 19 & 43 & 19 & 52 & 42 \\
5 & 62 & 71 & 53 & 68 & 27 & 45 & 30 & 42 \\
\hline
\end{tabular}

1: Kesinlikle katılmıyorum, 2: Katılmıyorum, 3: Kararsızım, 4: Katılıyorum, 5: Kesinlikle katılıyorum

Tablo 11'de verilen bilgiler dikkate alındığında öğretmen adaylarının arasında cinsiyet bağlamında her maddede farklılık olduğu görülmektedir. Bu fark her maddede erkekler lehine olarak belirlenmiştir. Farkın sırasıyla 23., 27., 30. ve 31. maddelerde olduğu tespit edilmiştir. Bu durumda erkek öğrenciler, Fransızcayı iyi düzeyde konuşabilmenin onlara dili kullanmak için birçok fırsat yaratacağını, iş bulmalarında avantaj sağlayacağını düşünmektedirler. Aynı zamanda, envantere verilen yanıtlardan, erkek öğrencilerin Türklerin yabancı bir dili konuşabilmeyi önemsediklerini düşündükleri ve Fransızca konuşan bireyleri daha iyi tanıyabilmek için bu dili öğrenmek istedikleri gözlenmiştir.

\section{Katılımcıların Dil Öğrenmeye Yönelik İnançlarının Sınıf Bağlamındaki Dağılımlarına İlişkin Bulgular}

Çalışmanın "Fransızca yabancı dil öğrencilerinin dil öğrenmeye yönelik inançları sınıf bağlamında nasıldır?" şeklindeki 3. sorusuna yanıt alabilmek için çapraz tablolama yöntemi kullanılmıştır. Bulgular alt boyutlar olan yabancı dil yatkınlığı, dil öğrenme güçlüğü, dil öğrenmenin doğası, öğrenme ve iletişim stratejileri, güdülenme ve beklentiler kapsamında yüzdelik olarak sunulmuştur.

Aşağıda sunulan Tablo 12'de görüldüğü üzere 10. madde haricinde tüm maddelerde sınıf düzeyinde çeşitli farklar belirlenmiştir. "Kesinlikle katılıyorum," yanıtının çoğunlukta olduğu maddelerden 1. maddede 4. sinıflar ile 2. sinıflar arasında, 2. madde de yine 4. siniflar ile 2. ve 3. sınıflar arasında, 34. maddede ise 3. sınıflar ile 1. sinıflar arasında fark olduğu görülmektedir. Bu farkların tümü büyük sınıflar lehinedir. Bu durumda, yabancı dil yatkınlı̆ı konusunda büyük sınıfların küçük sınıflara göre daha ön planda oldukları söylenebilir. Diğer yandan "Kesinlikle katılmıyorum," yanıtında yığılmanın yaşandığı maddelerden 22. maddede ilgi çekici bir sıralama (3, 1, 2 ve 4 biçimde) gözlenmektedir. Bundan farklı olarak 29. maddede ise 2, 1, 3 ve 4 biçimde farklı bir sıralama olduğu belirlenmiştir. Dolayısıyla, verilen yanıtlardan 22. ve 29. maddelerle ilgili olarak sınıf bağlamında bir tutarlılık söz konusu değildir. 
Tablo 12. Katılımcıların Sınıf Bağlamında Yabancı Dil Yatkınlığı Dağılımları

\begin{tabular}{|c|c|c|c|c|c|c|}
\hline Madde & Sinif & $\begin{array}{c}\text { Kesinlikle } \\
\text { Katılmıyorum }\end{array}$ & Katılmiyorum & Kararsızım & Katıliyorum & $\begin{array}{c}\text { Kesinlikle } \\
\text { Katılıyorum }\end{array}$ \\
\hline \multirow{4}{*}{$\mathrm{m} 1$} & 1 & 0 & 3 & 7 & 17 & 73 \\
\hline & 2 & 0 & 10 & 0 & 45 & 45 \\
\hline & 3 & 0 & 4 & 8 & 24 & 64 \\
\hline & 4 & 0 & 0 & 0 & 19 & 81 \\
\hline \multirow{4}{*}{$\mathrm{m} 2$} & 1 & 3 & 6 & 3 & 50 & 37 \\
\hline & 2 & 10 & 0 & 5 & 45 & 40 \\
\hline & 3 & 8 & 12 & 4 & 36 & 40 \\
\hline & 4 & 0 & 0 & 0 & 38 & 63 \\
\hline \multirow{4}{*}{$\mathrm{m} 10$} & 1 & 3 & 0 & 10 & 37 & 50 \\
\hline & 2 & 0 & 0 & 5 & 45 & 50 \\
\hline & 3 & 0 & 8 & 12 & 36 & 44 \\
\hline & 4 & 0 & 0 & 6 & 56 & 38 \\
\hline \multirow{4}{*}{ m15 } & 1 & 0 & 3 & 17 & 53 & 27 \\
\hline & 2 & 5 & 0 & 35 & 45 & 15 \\
\hline & 3 & 0 & 8 & 28 & 36 & 28 \\
\hline & 4 & 0 & 0 & 19 & 50 & 31 \\
\hline \multirow{4}{*}{$\mathrm{m} 22$} & 1 & 33 & 13 & 23 & 10 & 20 \\
\hline & 2 & 30 & 30 & 30 & 10 & 0 \\
\hline & 3 & 52 & 12 & 20 & 8 & 8 \\
\hline & 4 & 25 & 6 & 31 & 13 & 25 \\
\hline \multirow{4}{*}{$\mathrm{m} 29$} & 1 & 40 & 17 & 20 & 13 & 10 \\
\hline & 2 & 55 & 25 & 5 & 15 & 0 \\
\hline & 3 & 36 & 28 & 12 & 20 & 4 \\
\hline & 4 & 19 & 13 & 19 & 19 & 31 \\
\hline \multirow{4}{*}{$\mathrm{m} 32$} & 1 & 7 & 7 & 20 & 33 & 33 \\
\hline & 2 & 10 & 15 & 25 & 35 & 15 \\
\hline & 3 & 16 & 12 & 40 & 12 & 20 \\
\hline & 4 & 13 & 6 & 6 & 50 & 25 \\
\hline \multirow{4}{*}{$\mathrm{m} 33$} & 1 & 17 & 53 & 27 & 3 & 0 \\
\hline & 2 & 35 & 15 & 35 & 5 & 10 \\
\hline & 3 & 16 & 36 & 44 & 4 & 0 \\
\hline & 4 & 31 & 13 & 13 & 19 & 25 \\
\hline \multirow{4}{*}{$\mathrm{m} 34$} & 1 & 7 & 10 & 17 & 30 & 37 \\
\hline & 2 & 0 & 5 & 15 & 35 & 45 \\
\hline & 3 & 4 & 12 & 16 & 12 & 56 \\
\hline & 4 & 0 & 13 & 6 & 38 & 44 \\
\hline
\end{tabular}

Öğretmen adaylarının dil öğrenme güçlüğü alt boyutunun sınıf bağlamındaki dağıllımları aşağıda sunulan Tablo 13'te verilmiştir. Buna göre her maddede farklılık görülmüştür. Yığılmanın "Kesinlikle katılıyorum," seçeneğinde yaşandığı 3. ve 6. maddelerden ilkinde son sinıf öğrencilerinin önde, diğer soruda ise sonda olduğu bulunmuştur. "Katılıyorum," yanıtında yoğunluğun olduğu 14. maddede ise sınıf düzeyi arttıkça yüzdenin azaldığı gibi ilgi çekici bir bulgu belirlenmiştir. Katılımcıların "Kesinlikle katılmıyorum," yanıtında en çok birleştikleri madde olan 24. maddede ise 3. sınıflar ile 4. sınıflar arasında 3. sınıfların lehine fark bulunmuştur. 
Tablo 13. Katılımcıların Sınıf Bağlamında Dil Öğrenme Güçlüğü Dağılımları

\begin{tabular}{|c|c|c|c|c|c|c|}
\hline Madde & Sinif & $\begin{array}{c}\text { Kesinlikle } \\
\text { Katılmıyorum }\end{array}$ & Katılmıyorum & Kararsızım & Katılıyorum & $\begin{array}{l}\text { Kesinlikle } \\
\text { Katılıyorum }\end{array}$ \\
\hline \multirow{4}{*}{ M3 } & 1 & 0 & 0 & 0 & 37 & 63 \\
\hline & 2 & 0 & 0 & 0 & 40 & 60 \\
\hline & 3 & 4 & 8 & 8 & 28 & 52 \\
\hline & 4 & 0 & 6 & 0 & 19 & 75 \\
\hline \multirow{4}{*}{ M4 } & 1 & 0 & 17 & 30 & 40 & 10 \\
\hline & 2 & 0 & 0 & 45 & 50 & 5 \\
\hline & 3 & 0 & 4 & 48 & 44 & 4 \\
\hline & 4 & 6 & 6 & 31 & 31 & 25 \\
\hline \multirow{4}{*}{ M6 } & 1 & 3 & 0 & 13 & 40 & 47 \\
\hline & 2 & 0 & 0 & 20 & 35 & 45 \\
\hline & 3 & 0 & 4 & 16 & 36 & 44 \\
\hline & 4 & 0 & 6 & 19 & 50 & 25 \\
\hline \multirow{4}{*}{$\mathrm{m} 14$} & 1 & 0 & 0 & 17 & 73 & 10 \\
\hline & 2 & 5 & 5 & 10 & 65 & 20 \\
\hline & 3 & 0 & 4 & 16 & 48 & 32 \\
\hline & 4 & 0 & 6 & 25 & 25 & 44 \\
\hline \multirow{4}{*}{ M24 } & 1 & 17 & 33 & 30 & 7 & 13 \\
\hline & 2 & 15 & 30 & 35 & 15 & 5 \\
\hline & 3 & 28 & 28 & 24 & 16 & 4 \\
\hline & 4 & 6 & 31 & 19 & 19 & 25 \\
\hline \multirow{4}{*}{$\mathrm{m} 28$} & 1 & 10 & 20 & 23 & 17 & 30 \\
\hline & 2 & 5 & 40 & 40 & 5 & 10 \\
\hline & 3 & 4 & 8 & 20 & 28 & 40 \\
\hline & 4 & 6 & 19 & 19 & 25 & 31 \\
\hline
\end{tabular}

Katılımcıların dil öğrenmenin doğası alt boyutunun sınıf bağlamında 25. madde haricinde aralarında çeşitli farklar olduğu belirlenmiştir. Tablo 14'e göre "Kesinlikle katılıyorum," yanıtında yoğunluğun yaşandığ 1 . ve 16. maddelerde 2. sınıf ile 1. sinıf arasında büyük sinıf lehine fark olduğu görülmektedir. Bu durumda, 2. sınıfların Fransızcanın dil yapısının Türkçeninkinden farklı olduğu ve yabancı dil öğrenmenin sözcük öğrenmek olduğu konusunda yoğunlaştıkları söylenebilir. Bu alt boyuta ait sonraki madde olan 8. maddede ise son sinıflar ile 3. sınıflar arasında fark bulunmuştur. Birinci sınıf öğretmen adaylarının büyük bölümünün "Kesinlikle katılıyorum," yanıtını verdiği 11. maddede, 2. ve 3. sınıf katılımcıların daha düşük düzeyde kaldığı belirlenmiştir. 
Tablo 14. Katılımcıların Sınıf Bağlamında Dil Öğrenmenin Doğası Dağılımları

\begin{tabular}{|c|c|c|c|c|c|c|}
\hline Madde & Sinıf & $\begin{array}{c}\text { Kesinlikle } \\
\text { Katılmıyorum }\end{array}$ & Katılmiyorum & Kararsızım & Katıliyorum & $\begin{array}{c}\text { Kesinlikle } \\
\text { Katılıyorum }\end{array}$ \\
\hline \multirow{4}{*}{ m5 } & 1 & 0 & 0 & 17 & 43 & 40 \\
\hline & 2 & 0 & 0 & 0 & 30 & 70 \\
\hline & 3 & 0 & 0 & 4 & 32 & 64 \\
\hline & 4 & 0 & 0 & 0 & 38 & 63 \\
\hline \multirow{4}{*}{$\mathrm{m} 8$} & 1 & 3 & 17 & 10 & 37 & 33 \\
\hline & 2 & 10 & 10 & 5 & 35 & 40 \\
\hline & 3 & 0 & 12 & 20 & 44 & 24 \\
\hline & 4 & 0 & 6 & 6 & 31 & 56 \\
\hline \multirow{4}{*}{$\mathrm{m} 11$} & 1 & 0 & 0 & 7 & 13 & 80 \\
\hline & 2 & 0 & 0 & 10 & 45 & 45 \\
\hline & 3 & 0 & 0 & 12 & 40 & 48 \\
\hline & 4 & 0 & 0 & 13 & 13 & 75 \\
\hline \multirow{4}{*}{$\mathrm{m} 16$} & 1 & 0 & 7 & 7 & 40 & 47 \\
\hline & 2 & 0 & 5 & 5 & 65 & 25 \\
\hline & 3 & 4 & 8 & 12 & 48 & 28 \\
\hline & 4 & 0 & 13 & 13 & 44 & 31 \\
\hline \multirow{4}{*}{$\mathrm{m} 20$} & 1 & 3 & 30 & 17 & 33 & 17 \\
\hline & 2 & 5 & 10 & 40 & 20 & 25 \\
\hline & 3 & 12 & 20 & 28 & 24 & 16 \\
\hline & 4 & 6 & 6 & 31 & 31 & 25 \\
\hline \multirow{4}{*}{$\mathrm{m} 25$} & 1 & 3 & 7 & 10 & 40 & 40 \\
\hline & 2 & 0 & 5 & 25 & 20 & 50 \\
\hline & 3 & 4 & 0 & 20 & 28 & 48 \\
\hline & 4 & 0 & 0 & 31 & 25 & 44 \\
\hline \multirow{4}{*}{$\mathrm{m} 26$} & 1 & 13 & 23 & 23 & 27 & 13 \\
\hline & 2 & 20 & 30 & 25 & 25 & 0 \\
\hline & 3 & 12 & 12 & 44 & 16 & 16 \\
\hline & 4 & 0 & 19 & 19 & 38 & 25 \\
\hline
\end{tabular}

Aşağıda sunulan Tablo 15'te öğretmen adaylarının öğrenme ve iletişim stratejileri kapsamında verdikleri yanıtlarda, sınıf bağlamında 12., 18. ve 19. maddeler haricinde fark olduğu belirlenmiştir. Katılımcıların olumsuz görüş belirttikleri 9. maddede ilk 3 sınıfın son sınıflara göre daha olumsuz yanıtlara yöneldikleri görülmektedir. Buna göre, sınıf düzeyi arttıkça, yabancı bir dilin hata yapılarak da konuşulabileceği, hata yapma korkusuyla çekingen kalınmaması gerektiği konusunda öğrencilerin daha bilinçli oldukları söylenebilir. Öte yandan, öğrencilerin "Kesinlikle katılıyorum," yanıtında yoğunlaştıkları 13. maddede ise son sınıf öğrencilerinin diğer öğrencilerin önüne geçtiği belirlenmiştir. Benzer durumun son maddede yaşandığı yine Tablo 13'te görülmektedir. Bunlara ek olarak 17. maddede sınıf düzeyi arttıkça katılımcıların "Kesinlikle katılıyorum," yanıtına verdikleri oranın azaldığı şeklinde bir bulguya ulaşılmıştır. 
Tablo 15. Katılımcıların Sınıf Bağlamında Öğrenme ve İletişim Stratejileri Dağılımları

\begin{tabular}{|c|c|c|c|c|c|c|}
\hline Madde & Sinif & $\begin{array}{c}\text { Kesinlikle } \\
\text { Katılmiyorum }\end{array}$ & Katılmiyorum & Kararsızım & Katıliyorum & $\begin{array}{c}\text { Kesinlikle } \\
\text { Katılıyorum }\end{array}$ \\
\hline \multirow{4}{*}{$\mathrm{m} 7$} & 1 & 0 & 13 & 7 & 40 & 40 \\
\hline & 2 & 5 & 20 & 5 & 50 & 20 \\
\hline & 3 & 0 & 8 & 24 & 36 & 32 \\
\hline & 4 & 0 & 19 & 13 & 38 & 31 \\
\hline \multirow{4}{*}{ m9 } & 1 & 30 & 47 & 7 & 7 & 10 \\
\hline & 2 & 45 & 30 & 5 & 20 & 0 \\
\hline & 3 & 40 & 36 & 8 & 16 & 0 \\
\hline & 4 & 38 & 13 & 13 & 25 & 13 \\
\hline \multirow{4}{*}{$\mathrm{m} 12$} & 1 & 0 & 7 & 20 & 50 & 23 \\
\hline & 2 & 0 & 5 & 25 & 40 & 30 \\
\hline & 3 & 4 & 8 & 28 & 24 & 36 \\
\hline & 4 & 6 & 0 & 25 & 44 & 25 \\
\hline \multirow{4}{*}{$\mathrm{m} 13$} & 1 & 3 & 7 & 20 & 50 & 20 \\
\hline & 2 & 0 & 0 & 20 & 55 & 25 \\
\hline & 3 & 4 & 0 & 32 & 40 & 24 \\
\hline & 4 & 0 & 13 & 13 & 38 & 38 \\
\hline \multirow{4}{*}{$\mathrm{m} 17$} & 1 & 0 & 0 & 0 & 3 & 97 \\
\hline & 2 & 0 & 0 & 0 & 20 & 80 \\
\hline & 3 & 0 & 4 & 4 & 28 & 64 \\
\hline & 4 & 0 & 0 & 6 & 38 & 56 \\
\hline \multirow{4}{*}{$\mathrm{m} 18$} & 1 & 10 & 10 & 30 & 33 & 17 \\
\hline & 2 & 5 & 0 & 45 & 35 & 15 \\
\hline & 3 & 4 & 0 & 32 & 36 & 28 \\
\hline & 4 & 0 & 6 & 25 & 50 & 19 \\
\hline \multirow{4}{*}{ m19 } & 1 & 20 & 20 & 13 & 37 & 10 \\
\hline & 2 & 10 & 25 & 25 & 20 & 20 \\
\hline & 3 & 8 & 16 & 28 & 24 & 24 \\
\hline & 4 & 19 & 19 & 19 & 13 & 31 \\
\hline \multirow{4}{*}{$\mathrm{m} 21$} & 1 & 10 & 17 & 30 & 33 & 10 \\
\hline & 2 & 0 & 25 & 30 & 35 & 10 \\
\hline & 3 & 4 & 8 & 32 & 40 & 16 \\
\hline & 4 & 13 & 19 & 6 & 13 & 50 \\
\hline
\end{tabular}

Aşağıda verilen Tablo 16'da öğretmen adaylarının sınıflar bazında güdülenme ve beklentiler kapsamında verdikleri yanıtların genel olarak olumlu olduğu görülmektedir. Bu yanıtların hepsinde sınıflar arasında çeşitli farklar belirlenmiştir. Alt boyutun ilk maddesinde 1. ve 2. sinıflar ile 3. ve 4 . sınıflar arasında ilgi çekici bir fark bulunmuştur. Buna göre ilk iki sınıftaki öğrenciler "Kesinlikle katılıyorum," yanıtında yoğunlaşırken, bu durum son iki sınıfta azalmıştır. 27. ve 30. maddelerde ise 2. sınıflar en düşük dağılımı göstermiştir. Dolayısıyla, bu sınıf düzeyi ile diğer sınıf düzeyleri arasında farklılık olduğu belirlenmiştir. Buna göre, tüm sinıflardaki öğrenciler herkesin yabancı bir dil konuşabileceği konusunda hemfikirdirler. 
Tablo 16. Katılımcıların Sınıf Bağlamında Güdülenme ve Beklentiler Dağılımları

\begin{tabular}{ccccccc}
\hline Madde & Sinıf & $\begin{array}{c}\text { Kesinlikle } \\
\text { katılmiyorum }\end{array}$ & Katılmiyorum & Kararsızım & Katıliyorum & $\begin{array}{c}\text { Kesinlikle } \\
\text { Katılıorum }\end{array}$ \\
\hline \multirow{3}{*}{ m23 } & 1 & 0 & 0 & 7 & 20 & 73 \\
& 2 & 0 & 0 & 0 & 15 & 85 \\
& 3 & 0 & 0 & 16 & 40 & 44 \\
& 4 & 0 & 0 & 0 & 44 & 56 \\
& 1 & 0 & 7 & 7 & 20 & 67 \\
m27 & 2 & 5 & 0 & 15 & 35 & 45 \\
& 3 & 0 & 0 & 16 & 24 & 60 \\
& 4 & 0 & 0 & 19 & 25 & 56 \\
& 1 & 3 & 3 & 23 & 27 & 43 \\
m30 & 2 & 5 & 10 & 25 & 45 & 15 \\
& 3 & 0 & 16 & 12 & 36 & 36 \\
& 4 & 6 & 6 & 19 & 38 & 31 \\
& 1 & 0 & 3 & 3 & 57 & 37 \\
m31 & 2 & 0 & 0 & 15 & 50 & 35 \\
& 3 & 4 & 8 & 12 & 48 & 28 \\
& 4 & 0 & 6 & 25 & 31 & 38 \\
\hline
\end{tabular}

\section{Sonuç ve Tartışma}

Araştırmadan elde edilen sonuçlara ilişkin bulgular aşağıda alt boyutlarına göre tartışılmıştır.

1. "Katılımcıların Dil Öğrenmeye Yönelik İnanç Dağılımlarına İlişkin Bulguları”, "Yabancı dil yatkınlığı" alt boyutunda, katılımcıların büyük çoğunluğunun yabancı dil öğrenmede kızları ve erkekleri eşit düzeyde görmektedirler. Dolayısıyla, dile yatkınlık bağlamında, kızların erkeklere oranla daha üstün olmadıkları ve de cinsiyet faktörünün çok da önemli olmadığı söylenebilir. Aynı zamanda, katılımcıların büyük çoğunluğunun erken yaşta yabancı dil öğrenmenin daha kolay olduğu, bir dil bilmenin yeni bir dil öğrenmede kolaylık sağlayacağı ve Fransızcanın öğrenilmesi zor bir dil olduğu görüşünde hemfikir oldukları görülmektedir. Bu bulguların, Özçelik ve Topçu Tecelli'nin (2008) çalışmalarında elde ettikleri bulgularla benzerlik gösterdiğini söylemek mümkündür. Ayrıca, katılımcıların yabancı dil öğrenmede doğuştan gelen birtakım becerilerin etkili olabileceği konusunda da aynı fikri paylaşmakta oldukları söylenebilir. Buna göre, öğrencilerin dil öğrenmede bireyler arasındaki farklılıkların nedenini doğuştan gelen becerilere dayandırdıkları görülmektedir. Katılımcıların "Dil öğrenme gü̧̈lü̆ğ̈̈ne“ yönelik dağılımlarına bakıldığında, adayların bazı dillerin diğerlerine göre daha kolay öğrenildiği ve gelecekte Fransızca konuşmayı çok iyi öğrenebilecekleri konusunda hemfikir oldukları söylenebilir. Aynı zamanda, yabancı dilde konuşma becerisini kazanmanın daha zor olduğunu düşünmekte oldukları görülmektedir. Katılımcıların “Dil öğrenmenin doğasına" yönelik görüşlerinde ise, Fransızcanın dil yapısının Türkçeninkinden farklı olduğunu, yabancı dili en iyi o dilin konuşulduğu ülkede öğrenilebileceğini düşündükleri söylenebilir. Bu sonuçlar, iki dil arasındaki yapısal, biçimbilimsel ve biçimsözdizimsel farklılıklardan kaynaklanan 
öğrenme güçlüklerinin ortaya konduğu Topçu Tecelli ve Özçelik (2007) tarafından yapılan çalışmada elde edilen sonuçlarla örtüşmektedir. Aynı zamanda, dili konuşabilmek için o dilin kültürüne de hâkim olmaları gerektiğini düşündükleri görülmektedir. Böylelikle öğrencilerin, dil ve kültürün iç içe olduğu ve kelime dağarcığının da dili öğrenmede önemli olduğu konusunda duyarlı oldukları söylenebilir. Ayrıca, öğrencilerin yabancı dil öğrenmenin sadece dilbilgisi kurallarından ibaret olmadığı konusunda hemfikir oldukları görülmektedir. Adayların, "Öğrenme ve iletişim stratejilerine" ilişkin dağılımlarına gelince, sıklıkla dil öğrenmede tekrarın ve alıştırma yapmanın önemini vurgulamaktadırlar. Bunun yanı sıra, bir dili mükemmel bir telaffuz ve aksanla konuşmanın gerekliliğine inanmakta ve o dili konuşan kişilerle pratik yapma fırsatını değerlendirme konusunda istekli oldukları görülmektedir. Dili konuşurken hatalar yapılabileceği konusunda fikir birliği içinde oldukları söylenebilir. Dolayısıyla, iletişim kurarken hata yapmaktan çekinmedikleri, iletişime girmeye çalıştıkları söylenebilir. Adayların "Güdülenme ve beklentilere" yönelik tercihlerine bakıldığında genellikle olumlu yantlar verdikleri görülmektedir. Bu durumda, bir dili konuşabilmenin önemli olduğunu (Türklerin yabancı dil konuşabilmeye önem verdiklerini), dili iyi konuşabilmenin onlara çeşitli fırsatlar yaratacağını, iş imkânı sağlayacağını düşünmektedirler. Bu konudaki güdülenmelerinin oldukça yüksek olduğu söylenebilir.

2. "Katılımcıların Dil Öğrenmeye Yönelik İnançlarının Cinsiyet Bağlamındaki” dağılımlarına yönelik bulgulara bakıldığında, "Yabancı dil yatkınlı̆̆ı" alt boyutu kapsamında, erkek öğrencilerin kız öğrencilere göre, bir yabancı dil biliyor olmanın diğer dilleri daha kolay öğreneceklerini ve herkesin yabancı dil öğrenebileceğini daha fazla düşündükleri söylenebilir. Diğer yandan, kız öğrencilerin bir kısmı dil öğrenmeye daha yatkın olduklarını belirtmişlerdir. Erkek öğrenciler ise dil öğrenmeye yatkınlık konusunda cinsiyetin önemli olmadığını düşünmektedirler. "Dil öğrenme güu̧lü̆̆̈̈̈" alt boyutuna bakıldığında, hem kız hem de erkek öğrencilerin büyük çoğunluğu bazı dillerin daha kolay öğrenildiğini, öğrenmekte oldukları dili ileride iyi düzeyde konuşabileceklerini ve Fransızca okuma ve yazma becerilerinin anlama ve konuşma becerilerine göre daha kolay öğrenilebileceğini belirtmişlerdir. "Dil öğrenmenin doğası" dağılımlarına bakıldığında erkek öğrenciler, Fransızcanın yapısının Türkçeninkinden farklı olduğunu bir dili konuşabilmek için o dilin kültürünü de bilmeleri gerektiğini, bir dili en iyi biçimde o dilin konuşulduğu ülkede öğrenileceğini daha fazla belirtmişlerdir. Aynı zamanda, öğrencilerin dil öğrenmede sözcük dağarcığının ve dilbilgisi kurallarını bilmenin önemli olduğunu, dil öğrenmenin diğer dersleri öğrenmekten farklı olduğunu düşündükleri söylenebilir. "Öğrenme ve iletişim stratejileri" alt boyutu dağılımlarına bakıldığında, bazı maddelere erkek öğrenciler daha yoğunlukla katıldıklarını belirtmişlerdir. Bunlar, Fransızca konuşan kişilerle pratik yapma isteği, bilmedikleri sözcüklerin anlamını tahmin etme, bol bol tekrar çalışması yapma şeklindedir. Kız öğrenciler ise, hiç hata yapmadan yabancı dil konuşulamayacağını, hatalara rağmen 
bu dili kullanmaya çalışmak gerektiğini düşünmektedirler. "Güdülenme ve beklentiler" alt boyutuna bakıldığında, neredeyse her maddede farklılık olduğu görülmektedir. Bu farkın erkek öğrenciler lehine olduğu söylenebilir.

3. "Katılımcıların Dil Öğrenmeye Yönelik İnançlarının Sınıf Bağlamındaki" dağılımlarında, "Yabancı dil yatkınlı̆̆ı" ile ilgili bulgulara göre, oluşan farklılıkların tamamının büyük sınıflar lehine olduğu görülmektedir. Buna göre, yabancı dil yatkınlığı konusunda büyük sınıfların daha ön planda oldukları söylenebilir. Adayların “Dil öğrenme gü̧̈lüğü "alt boyuna ait bulgularına göre, yabancı dili akıcı bir biçimde konuşabilmek için uzun zaman ayırmak gerektiği konusunda, sınıf düzeyi arttıkça "Katılıyorum," yüzdesinin arttığı görülmektedir. Bir dilde duyduğunu anlama becerisinin konuşma becerisine göre daha zor geliştiği konusunda da 3. sınıfların lehine fark bulunmuştur. "Dil öğrenmenin doğasına" ait bulgularda yoğunluk 2. sınıfların lehine görünmektedir. Buna göre, 2. sınıf öğrencileri Fransızcanın dil yapısının Türkçeninkinden farklı olduğu ve yabancı dil öğrenmenin aynı zamanda sözcük dağarcığını geliştirmek olduğunun bilincinde oldukları görülmektedir. Ayrıca, 1. sınıf öğrencilerinin bir dili en iyi şekilde o dilin konuşulduğu ülkede öğrenileceği konusunda diğer sınıflara göre daha yüksek inanışta oldukları görülmüştür. Katılımcıların, "Öğrenme ve iletişim stratejileri" kapsamında verdikleri yanıtlardan, sınıf düzeyi arttıkça, yabancı dilin hata yapılarak da konuşulabileceği, hata yapma korkusuyla çekingen kalınmaması gerektiği konusunda öğrencilerin daha bilinçli oldukları söylenebilir. Ayrıca, yabancı dilde bilinmeyen bir sözcüğün tahmin edilebileceği konusunda da son sınıf öğrencilerinin diğer sınıflara oranla çoğunlukta oldukları gözlenmiştir. Adayların “Güdülenme ve beklentiler" alt boyutu kapsamında verdikleri yanıtların genel olarak olumlu olduğu ve güdülenme düzeylerinin yüksek olduğu söylenebilir.

\section{Kaynaklar}

Altan, M. X. (2006). Beliefs about language learning of foreign language- major university students. Australian Journal of Teacher Education, 31(2).

Arıoğlu, S., Dalım, Ç. Ü. ve Onursal, İ. (2009). Foreign language learners' beliefs about language learning: a study on Turkish university students. Procedia Social and Behavioral Sciences, 1, 15001506.

Arnold, J. (2006). Comment les facteurs affectifs influencent-ils l'apprentissage d'une langue étrangère?. Ela-Études de Linguistique Appliquée, 144 (4), 407-425.

Bagherzadeh, H. (2012). Language learning beliefs of non-English majors: Examining the role of English language proficiency. Journal of Language Teaching and Research, 3 (4), 784-792. 
Banya, K. ve Cheng, M. H. (1997). Beliefs about foreign language learning: a study of beliefs of teachers' and students' cross cultural settings. Paper presented at the 31st Annual TESOL Convention, March 11-15, USA.

Bernat, E. ve Lloyd, R. (2007). Exploring the gender effect on Efl learners' beliefs about language learning. Australian Journal of Educational \& Developmental Psychology, 7, 79-91.

Bernat, E. ve Gvozdenko, I. (2005). Beliefs about language learning: current knowledge, pedagogical implications and new research directions. TESL-EJ: Teaching English as a Second or Foreign Language, 9 (1), 1-21.

Dağgöl, G. D. ve Akçayoğlu, D. İ. (2017). A look into the language learning beliefs: English-major and non-English major students. Turkish Studies, 12, 133-154.

Horwitz, E. K. (1988). The beliefs about language learning of beginning university foreign language students. The Modern Language Journal, 72(3), 283-294.

Huang, S. C. ve Tsai, R. R. (2003). A comparison between high and low English proficiency learners' beliefs. ERIC- Report/Research, Taiwan.

Jee, M. J. (2013). Beliefs about language learning: a study of American University students learning Korean. Language Research, 49 (2), 399-418.

Jelakovic, M. (2014). Motivation et attitudes des apprenants de la langue Française. Thèse de Maîtrise Non Publié. Croatie.

Kaçar, I. G. ve Zengin, B. (2009). İngilizceyi yabancı dil olarak öğrenenlerin dil öğrenme ile ilgili inançları, öğrenme yöntemleri, dil öğrenme amaçları ve öncelikleri arasındaki ilişki: Öğrenci boyutu. Journal of Language and Linguistic Studies, 5 (1), 55-89.

Kunt, N. (2008). Beliefs about language learning: a study of International University students learning Turkish as a second language. Dil bilim Araştırmaları, 64-75.

Longpré, T. (2015). Les facteurs affectifs dans l'apprentissage du Français chez les immigrants allophones adultes à Montréal. Canadian Journal for New Scholars in Education, 6 (2), 62-72.

Mori, Y. (1997). Epistemological beliefs and language learning beliefs: what do language learners believe about their learning?. Annual Meeting of the American Educational Research Association, USA, March 24-28.

Nikitina, L. ve Furuoka, F. (2006). Re-examining Horwitz's beliefs about language learning inventory (BALLI) in the Malaysian context. Electronic Journal of Foreign Language Teaching, 3 (2), 209-219.

Özçelik, N. ve Topçu Tecelli, N. (2008). Causes des difficultés de l'écrit en français chez les étudiants Turcs. Gazi Üniversitesi Gazi Ĕ̆itim Fakültesi Dergisi, 3, 99-123. 
Peacock, M. (2001). Pre-Service Esl teachers' beliefs about second language learning: A longitudinal study. System, 29, 177-195.

Topçu Tecelli, N. ve Özçelik, N. (2007). Fransızca dilbilgisi öğreniminde üniversite öğrencilerinin karşılaştıkları güçlükler: Fransızca ve Türkçede sözdizimsel ve biçimbilimsel farklılıklar. Hacettepe Üniversitesi Eğitim Fakültesi Dergisi, 32, 282-293.

\section{Extended Summary}

\section{An Analysis of the Beliefs of Students Studying French as a Foreign Language in Learning a Language within the Context of Various Variables}

With the adoption of the understanding of education that takes the student to the center of education, it has begun to focus on various factors affecting the education process of the students. Accordingly, the emotional states of students, such as motivation, anxiety, and belief, have become the focus of research. Therefore, in order to provide better education to students in foreign language teaching as in all areas of education and training process, it has become necessary to investigate the psychological factors affecting them.

In this study, it is aimed to analyze the beliefs of first, second, third, and fourth grade students studying French as a foreign language in learning language based on various variables. The research was carried out with 91 students studying in a state university in Eskişehir, Faculty of Education, Department of Foreign Languages Education, French Teaching Program, during the academic year of 2018-2019. In this descriptive research, the screening model was used.

The quantitative data of the research were collected using the BALLI - Beliefs About Language Learning Inventory, which was developed by Horwitz (1988) in order to identify the belief of students studying English Language in learning language. This questionnaire comprises 34 items categorized under "Foreign Language Aptitude", "The Nature of Language Learning", "The Difficulty of Language Learning", "Learning and Communication Strategies", and "Motivation and Expectations". The qualitative data analysis program (SPSS) and cross tabulation method were used to analyze the qualitative data of the research.

Examining the "Findings from the Belief Distribution of Participators in Language Learning" under the sub-dimension of "Foreign Language Aptitude", it is seen that the majority of the participators recognize women and men equal in terms of learning a foreign language. Based on the distribution of participants with regards to "The Difficulty of Language Learning", it can be said that they agree on the idea that some languages are easier to learn compared to others and that they will be able to have excellent control over French. Concerning their thoughts on "The Nature of Language Learning", they seem to lean towards the idea that one can learn and have better control over a foreign language when he/she is in the country where that foreign language is spoken. It can also be seen that 
they support the idea that to have good knowledge of the culture of the language is good for having better control over that language. Therefore, what we conferred was that the students were aware of the significance of the vocabulary skills and that the language and the culture commune with each other. When we look at the distribution of candidates with regards to "Learning and Communication Strategies", what is emphasized by them is practicing and doing exercises on the language learning process. Accordingly, they think that it is important to be able to speak a foreign language, that having good control over a foreign language may present them various chances, including business opportunities.

Examining the "Findings from the Belief Distribution of Participators in Language Learning" under the sub-dimension of "Foreign Language Aptitude", it can be said that the ratio of male students who think that speaking a foreign language may render it easier to learn another foreign language and that everyone can learn a foreign language is higher than the female students. Within the subdimension of "The Difficulty of Language Learning", the majority of both female and male students stated that certain languages are easier to learn, that they will be able to have excellent control over the foreign language in the future, and that reading \& writing in French is easier compared to speaking it. When we look at the distribution in "The Nature of Language Learning", the ratio of male students who stated that the grammatical structure of French is different than the one of Turkish, that it is a must for one to have good cultural knowledge in the language he/she is learning, and that it is easier to learn a language in the country where that language is officially spoken by the public, is higher compared to the female students. Examining the distribution of the sub-dimension "Learning and Communication Strategies", the male students were seen to be more positive in terms of having the intention of practising with native French speakers, as well as guessing the meaning of a word which is unknown to them, and practising more and more in the language learning process. Under the subdimension of "Motivation and Expectations", it can be seen that there is a difference in almost every item on the questionnaire, which is in favour of the male students.

According to the "Findings from the Belief Distribution of Participators in Language Learning" under the sub-dimension of "Foreign Language Aptitude", it can be said that the senior classes come to the forefront in terms of foreign language aptitude. As per the answers of the candidates under the sub-dimension of "The Difficulty of Language Learning", the ratio of those with the thought that having excellent control over a foreign language requires devotion gets higher in direct proportion to the grade of students. Based on the findings from the sub-dimension of "The Nature of Language Learning", it can be said that the $2^{\text {nd }}$ grade students are more aware of the fact that the grammatical structure of French is different than the one of Turkish, and that learning a language not only paves the way for, but also renders it as a must to improve the vocabulary of anyone learning a foreign language. 
From the answers given by the candidates under the sub-dimension of "Learning and Communication Strategies", it can also be said that the ratio of students with the opinion that one can speak a language even if he/she makes a mistake, and that making a mistake should not be recognized as a reason for lack of motivation, gets higher in direct proportion to the grade of students. When we look at the answers given by the candidates under the sub-dimension of "Motivation and Expectations", it can be said that the motivation levels of the participants are high.

EK:

\section{DİL ÖĞRENIMINE YÖNELIK İNANÇLAR ENVANTERİ}

(BALLI-Beliefs About Language Learning Inventory)

Bu envanterin amacı Fransızca öğrenme hakkındaki inanışlarınıza ilişkin bilgi sahibi olmaktır. Bu envanterdeki soruların doğru cevabı yoktur, önemli olan sizin düşüncelerinizi öğrenmektir.

Araştırmadan elde edilen veriler gizli tutulacaktır. Lütfen soruları dikkatlice okuyunuz (4. ve 14. sorular çoktan seçmelidir). Duygu ve düşüncelerinize en uygun olan seçeneği ilgili sütuna " $X$ " koyarak işaretleyiniz.

Katkılarınız için teşekkür ederim. (:)

Cinsiyet: $\square \mathrm{K}$ $\square \mathrm{E}$

\begin{tabular}{|c|c|c|c|c|c|c|}
\hline & Maddeler & 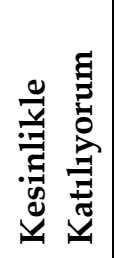 & 胥 & 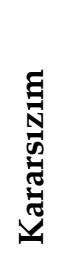 & 宓 & 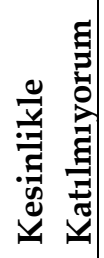 \\
\hline 1 & It is easier for children than adults to learn a foreign language. & & & & & \\
\hline 2 & $\begin{array}{l}\text { Some people are born with a special ability which helps them learn a } \\
\text { foreign language. }\end{array}$ & & & & & \\
\hline 3 & Some languages are easier to learn than others. & & & & & \\
\hline 4 & $\begin{array}{l}\text { The language I am trying to learn is: } \\
\text { a) very difficult } \\
\text { b) difficult } \\
\text { c) medium difficulty } \\
\text { d) easy } \\
\text { e) very easy }\end{array}$ & & & & & \\
\hline 5 & The structure of French is different from that of Turkish. & & & & & \\
\hline 6 & I believe that I will ultimately learn to speak this language very well. & & & & & \\
\hline 7 & $\begin{array}{l}\text { It is important to speak a foreign language with an excellent } \\
\text { pronunciation and accent. }\end{array}$ & & & & & \\
\hline 8 & $\begin{array}{l}\text { It is necessary to know the foreign culture in order to speak the foreign } \\
\text { language. }\end{array}$ & & & & & \\
\hline 9 & $\begin{array}{l}\text { You shouldn't say anything in the foreign language until you can say it } \\
\text { correctly. }\end{array}$ & & & & & \\
\hline 10 & $\begin{array}{l}\text { It is easier for someone who already speaks a foreign language to learn } \\
\text { another one. }\end{array}$ & & & & & \\
\hline
\end{tabular}




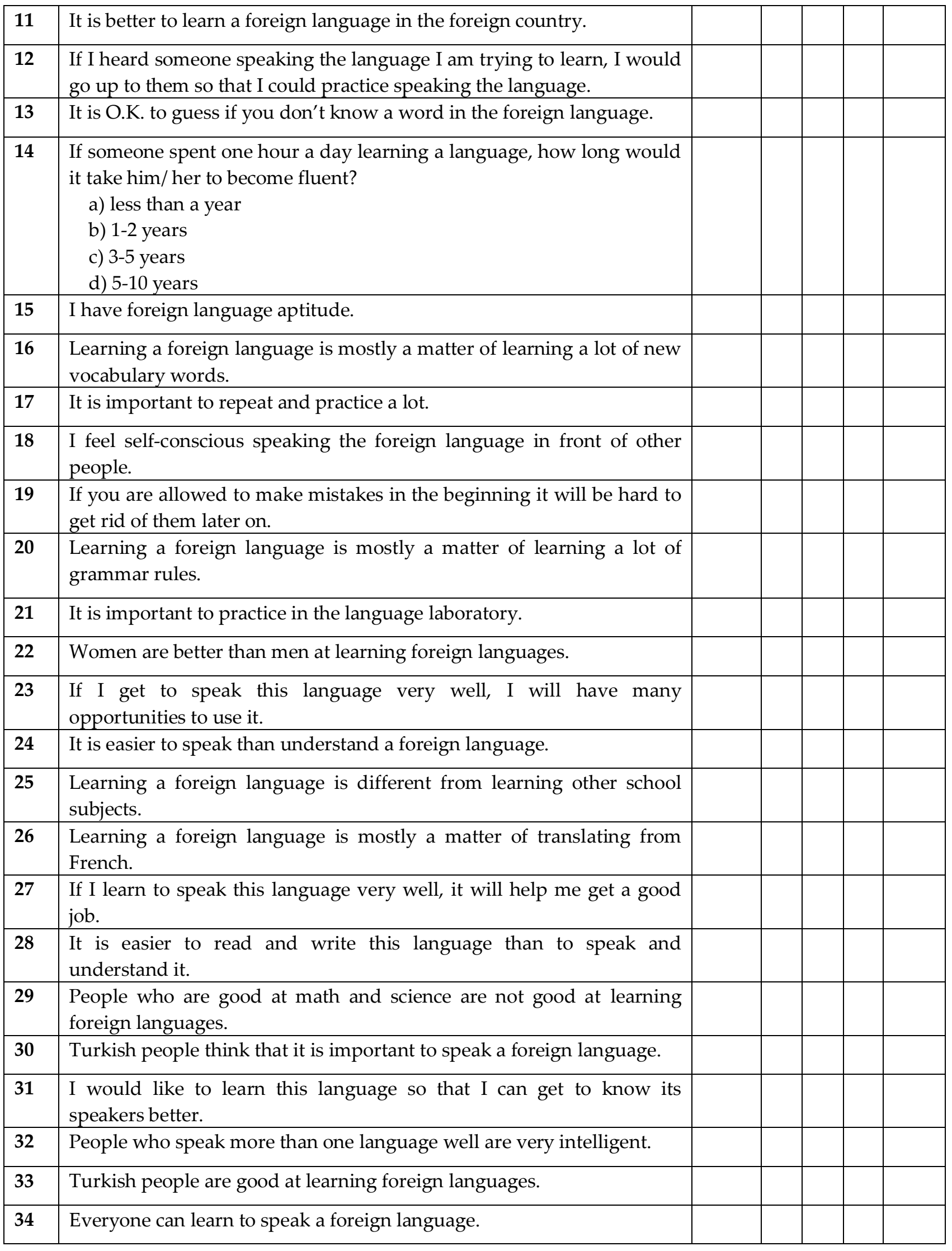

